\title{
Kinetika Pengeringan Busa Ampas Seduhan Teh
}

\author{
Indah Hartati $^{1 *}$, dan Maharani Kusumaningrum ${ }^{2}$ \\ ${ }^{7} J u r u s a n$ Teknik Kimia, Fakultas Teknik, Universitas Wahid Hasyim \\ Jl. Menoreh Tengah X No.22, Sampangan, Semarang, Jawa Tengah 50232 Indonesia \\ 'Jurusan Teknik Kimia, Fakultas Teknik, Universitas Negeri Semarang \\ Jl. Raya Sekaran, Gunungpati, Semarang, 50229, Indonesia \\ Email: hartatiprasetyo@gmail.com
}

\begin{abstract}
Abstrak
Dominasi produksi minuman teh dalam kemasan berdampak pada meningkatnya produksi limbah ampas seduhan teh yang masih memiliki kandungan berbagai metabolit sekunder, mineral, serat dan protein. Metode pengeringan busa (foam mat drying) dapat diterapkan pada produksi serbuk ampas seduhan teh guna mendukung pengembangan dan pemanfaatan lebih lanjut dari ampas seduhan teh. Tujuan penelitian ini adalah mengkaji pengaruh penambahan konsentrasi busa putih telur pada proses pengeringan busa ampas seduhan teh serta mengkaji kinetika pengeringan lapis tipis menggunakan model kinetika Newton/Lewis, Page, Henderson-Pabis, Logartitmic dan Two Term. Parameter proses yang dievaluasi meliputi variasi penambahan busa putih telur (7,5-15\%) sementara kadar maltodekstrin yang ditambahkan sebesar $30 \%$ dan pengeringan dilakukan pada suhu $800 \mathrm{C}$. Penelitian menunjukkan jika penggunaan busa putih telur 7,5\% memberikan kontanta kecepatan pengeringan yang lebih tinggi bila dibandingkan penggunaan busa putih telur $10-15 \%$. Dalam penelitian ini, model kinetika Page merupakan model yang memberikan kesesuaian yang lebih tinggi bila dibandingkan dengan model kinetika Newton/Lewis, Henderson and Pabis, Logartitmic dan Two Term.
\end{abstract}

Kata Kunci: kinetika pengeringan, ampas teh, busa putih telur

\section{Abstract \\ Foam Mat Drying Kinetics of Spent Tea Waste}

The emerging growth of tea based beverage impacts on the abundance of spent tea waste, a solid waste in which rich of secondary metabolites, minerals, fibre and protein. Foam mat drying of spent tea leaves powder is applied for further utilization of spent tea waste. The objective of this research was to investigate the influence of egg white concentration added in the foam mat drying of spent tea waste and investigate the foam mat drying kinetics. The thin layer drying kinetics models applied were Newton/Lewis, Page, Henderson-Pabis, Logartitmic and Two Term model. The egg white concentration were varied of 7,5-15\%, meanwhile the maltodextrin was of $30 \%$ and the the drying processes were performed at temperature of $80^{\circ} \mathrm{C}$. The research showed that the foam mat drying of spent tea waste performed at egg white concentration addition of 7,5\% gave higher drying rate constant. In this research, Among the empirical models applied in this research, Page model was found to be the most adequate model representing the drying behavior of spent tea waste.

Keywords: drying kinetics, spent tea leaves, foam mat drying

\section{PENDAHULUAN}

Karakteristik sensori, efek stimulan dan potensi efek kesehatan yang beragam telah menempatkan teh, minuman tradisional yang berasal dari China, sebagai minuman yang paling populer didunia setelah air putih (Ramdani et al., 2013; Barus et al., 2018; Tfouni et al., 2017). Tfouni 
et al. (2017) menyatakan jika aroma, rasa dan bau yang menyenangkan merupakan karakteristik sensori utama dari teh yang mendukung kepopuleran teh. Efek stimulan dari teh berasal dari keberadaan kafein, suatu turunan alkaloid xanthine termetilasi, yang mencapai $6,2-31,7 \%$ pada daun teh dan mencapai $4-14,9 \%$ pada seduhan teh (Cappelletti et al., 2015; Tfouni et al., 2017). Sementara itu teh juga dinyatakan memiliki berbagai efek kesehatan seperti: (i) efek kemopreventif yang mampu menginaktifkan radikal bebas, (ii) antikariogenik, (iii) anti inflamatory, dan (iv) anti karsinogenik (Barus et al., 2018).

Sebagai minuman yang populer, produksi teh di dunia semakin meningkat dan mencapai 5,07 juta ton pada tahun 2013. Sementara itu, menurut Dirjen Perkebunan, produksi teh di Indonesia diperirakan mencapai 146 ribu ton pada tahun 2017 (Direktorat Perkebunan, 2016). Di Indonesia, industri minuman teh didominasi oleh produksi minuman seduhan teh yang dikemas dalam botol, yang mencapai $28 \%$ dari pasar minuman di Indonesia. Teh botol diproduksi melalui proses penyeduhan teh dengan air dengan rasio teh:air yang cukup tinggi untuk mendapatkan kosentrat air seduhan teh. Sebagai hasil dari proses tesebut diperoleh ampas seduhan teh yang masih memiliki sebagian besar kandungan teh yang terdiri dari metabolit sekunder seperti senyawa phenolik yang besifat antioksidan, protein, asam amino, lipida,vitamin, serat, mineral, dan gula (Ramdani et al., 2016). Ramdani et al. (2013) menyatakan jika ampas seduhan teh yang diperoleh dari proses penyeduhan $5,6 \mathrm{~g}$ teh/300 $\mathrm{ml}$ air masih memiliki kandungan protein sebesar $248 \mathrm{~g} / \mathrm{kg}$, total phenol sebesar $113 \mathrm{~g} / \mathrm{kg}$, total tanin sebesar $107 \mathrm{~g} / \mathrm{kg}$, dan total saponin sebesar $53 \mathrm{~g} / \mathrm{kg}$. Ampas seduhan teh juga dinyatakan masih memiliki berbagai kandungan mineral seperti Ca (8581 $\mathrm{mg} / \mathrm{kg})$, K (2532 mg/kg), P (2058 mg/kg), dan Mg $(1744 \mathrm{mg} / \mathrm{kg})$, serta sejumlah kecil mineral $\mathrm{Mn}, \mathrm{Fe}$, $\mathrm{Na}, \mathrm{Cu}, \mathrm{Zn}, \mathrm{Ni}, \mathrm{Cr}, \mathrm{Pb}$ dan $\mathrm{Cd}$ (Ramdani et al., 2013). Farhoosh et al. (2007) dalam Hartati et al. (2018) juga menyatakan jika ampas teh memiliki aktivitas antioksidan yang tinggi serta mengandung serat kasar, selulosa, lignin dan berbagai macam mineral seperti karbon organik, tembaga $(\mathrm{Cu}) 20 \%$, magnesium $(\mathrm{Mg}) 10 \%$, dan kalsium $13 \%$.

Menimbang potensi kandungan berbagai metabolit sekunder pada ampas seduhan teh, maka pengeringan serbuk ampas teh dapat mendukung pengembangan dan pemanfaatan lebih lanjut dari ampas seduhan teh yang kaya akan mikronutrient. Secara umum, proses pengeringan yang merupakan proses pengurangan kadar air pada bahan yang akan menghasilkan produk kering dengan umur simpan yang lebih lama dan memiliki nilai water activity $\left(a_{w}\right)$ lebih rendah, diklasifikasikan menjadi tiga yakni pengeringan konduktif, konvektif dan radiatif (Hartati et al., 2018). Produk pangan dengan kadar air dan nilai $a_{w}$ yang rendah akan memiliki berat dan volume yang lebih ringan dan kecil, yang pada akhirnya berdampak pada penurunan biaya pengemasan, penyimpanan dan transportasi. Salah satu teknik pengeringan konvektif yang dapat diaplikasikan pada pengeringan serbuk ampas teh adalah pengeringan busa (Foam Mat Drying). Hartati et al. (2018) mengkaji pengaruh konsentrasi maltodestrin dan mengaji kinetika pengeringan ampas seduhan teh menggunakan model kinetika Lewis, Page dan Henderson-Pabis. Dalam artikel ini disajikan kajian pengaruh penambahan konsentrasi busa putih telur pada pengeringan busa ampass seduhan teh dan mengkaji kinetika pengeringan menggunakan model kinetika pengeringan lapis tipis.

\section{METODOLOGI}

Ampas teh yang digunakan dalam penelitian ini adalah ampas teh yang didapatkan dari limbah rumah tangga. Agen pembuih dan pembusa yang digunakan adalah maltodekstrin dan putih telur.

Ampas seduhan teh diperoleh dari proses infusi teh menggunakan air bersuhu $80^{\circ} \mathrm{C}$. Ampas teh yang diperoleh digunakan sebagai bahan baku proses pengeringan busa. Proses pengeringan busa dilakukan dengan menambahkan maltodekstrin sebesar 30\% dan busa putih telur sebesar 15\%. Sampel yang diperoleh dikeringkan menggunakan oven bersuhu $50-70^{\circ} \mathrm{C}$ dan dianalisa kadar airnya setiap interval waktu 10 menit. 
Data kadar air digunakan untuk menentukan nilai moisture ratio dengan rumus :

$$
M R=\frac{M_{t}-M_{e}}{M_{0}-M_{e}}
$$

dimana $M_{0}$ adalah kadar air awal, $M_{t}$ adalah kadar air pada t tertentu, dan $M_{e}$ adalah kadar air pada kondisi setimbang.

Model kinetika pengeringan yang digunakan untuk menganalisa kinetika pengeringan ampas seduhan teh disajikan pada Tabel 1 dan nilai RMSE ditentukan dengan rumus:

$$
R M S E=\left[\frac{1}{N} \sum_{i=1}^{N}\left(\mathrm{MR}_{p r e, i}-\mathrm{MR}_{e k s, i}\right)^{2}\right]^{1 / 2}
$$

\section{HASIL DAN PEMBAHASAN}

Pengeringan busa merupakan proses dimana produk yang berada dalam fase cair, semipadat atau padat, diubah menjadi busa yang stabil melalui penambahan agen pembusa dan penstabil, serta lebih lanjut dikeringkan menggunakan udara pengering (Sangamithra et al., 2015; Hardy et al., 2017). Pembentukan busa yang stabil merupakan salah satu poin penting penentu keberhasilan proses pengeringan busa (Sangamithra et al., 2015). Protein merupakan agen pembusa yang juga memiliki fungsi sebagai penstabil busa yang disebabkan oleh sifat kehidrofobikannya. Beberapa jenis protein yang kerap digunakan dalam proses pengeringan busa adalah putih telur, gelatin, whey protein dan protein kedelai. Dalam penelitian ini, putih telur merupakan protein yang digunakan dalam proses pengeringan busa ampas seduhan teh. Konsentrasi busa putih telur divariasi dari 7,5\% hingga $15 \%$.

Gambar 1 menunjukkan profil kadar air dari serbuk ampas seduhan teh yang dikeringkan dengan penambahan maltodekstrin $30 \%$, suhu $80^{\circ} \mathrm{C}$ dan penambahan busa putih telur $7,5-15 \%$. Penambahan busa putih telur dengan konsentrasi
$10 \%$ memberikan penurunan kadar air yang paling rendah bila dibandingkan dengan proses dengan penambahan busa putih telur dengan konsentrasi 7,5\%, 12\% maupun 15\%. Penurunan kadar air terbesar diperoleh pada penambahan busa putih telur dengan konsentrasi 7,5 \%, dan selanjutnya diikuti oleh proses dengan penambahan busa putih telur dengan konsentrasi $15 \%$ dan $12 \%$. Hasil penelitian ini menunjukkan jika dengan penambahan konsentrasi putih telur yang rendah mampu menghasilkan penurunan kadar air yang tinggi proses pengeringan busa ampas seduhan teh. Hal ini sesuai dengan pernyataan Mounir (2017) bahwa agen pembusa berbasis protein sebaiknya memiliki tiga karakteristik yakni: (i) mampu menstabilkan busa secara cepat dan pada konsentrasi yang rendah, (ii) efektif pada berbagai range $\mathrm{pH}$, dan (iii) efisien bahkan pada media yang memiliki inhibitor busa seperti lemak, alkohol dan senyawa flavour. Putih telur mampu menghasilkan busa protein yang bagus karena protein yang terkandung didalammya memiliki karakteristik yang sesuai untuk pembusaan. Karakteristik dari protein pada telur antara lain: protein putih telur mampu dengan cepat terserap pada interface udara-air selama proses whipping, dan protein pada telur mampu membentuk lapisan film yang bersifat viscoelastik kohesif (Lomanika dan Mikova, 2006).

Selanjutnya profil laju pengeringan dari proses pengeringan busa ampas seduhan teh yang dilakukan menggunakan busa putih telur dengan konsentrasi 7,5-15\%, baik terhadap kadar air maupun terhadap durasi pengeringan disajikan pada Gambar 2. Seperti terlihat pada Gambar 2b, pada periode awal proses pengeringan (0-20 menit), laju pengeringan busa ampas seduhan the yang dilakukan menggunakan busa putih telur dengan konsentrasi 7,5\% relatif lebih cepat bila dibandingkan dengan proses dengan penambahan konsentrasi 10-15\%. Sementara

Tabel 1. Model kinetika pengeringan

\begin{tabular}{lll}
\hline \multicolumn{1}{c}{ Model Kinetika } & \multicolumn{1}{c}{ Persamaan Model Kinetika } & Referensi \\
\hline Newton/Lewis & $M R=\exp (-k t)$ & Inyang et al., 2018 \\
Page & $M R=\exp \left(-k t^{n}\right)$ & \\
Henderson Pabis & $M R=a \exp (-k t)$ & \\
Logaritmic & $M R=a \exp (-k t)+\mathrm{c}$ & \\
Two term & $M R=a \exp \left(-k_{0} t\right)+b \exp \left(-k_{1} t\right)$ & \\
\hline
\end{tabular}




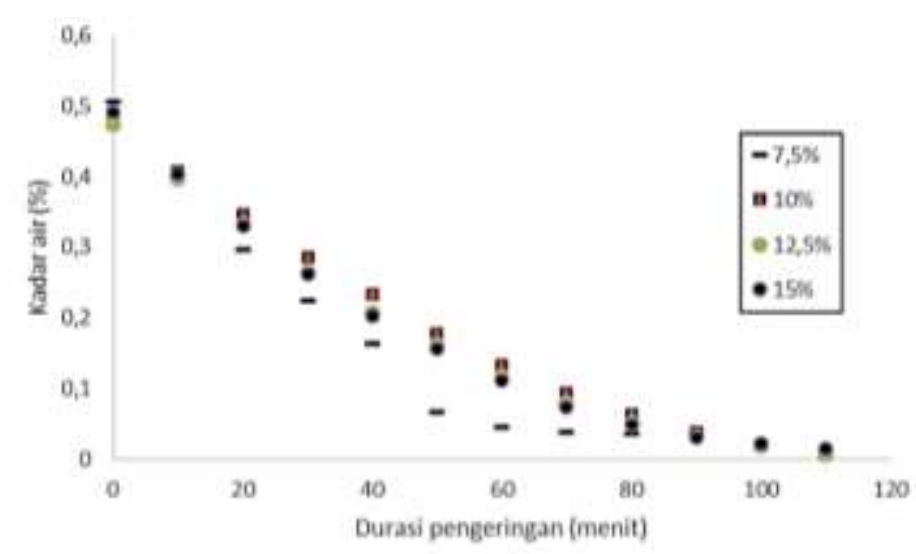

Gambar 1. Kadar air serbuk ampas teh yang dikeringkan dengan pengeringan busa menggunakan maltodekstrin $30 \%$, suhu $80^{\circ} \mathrm{C}$ dan penambahan busa putih telur $7,5-15 \%$

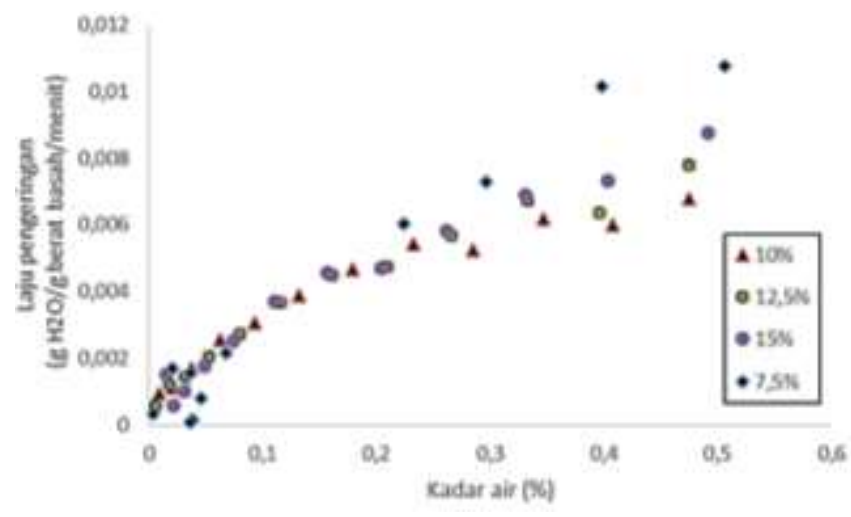

(a)

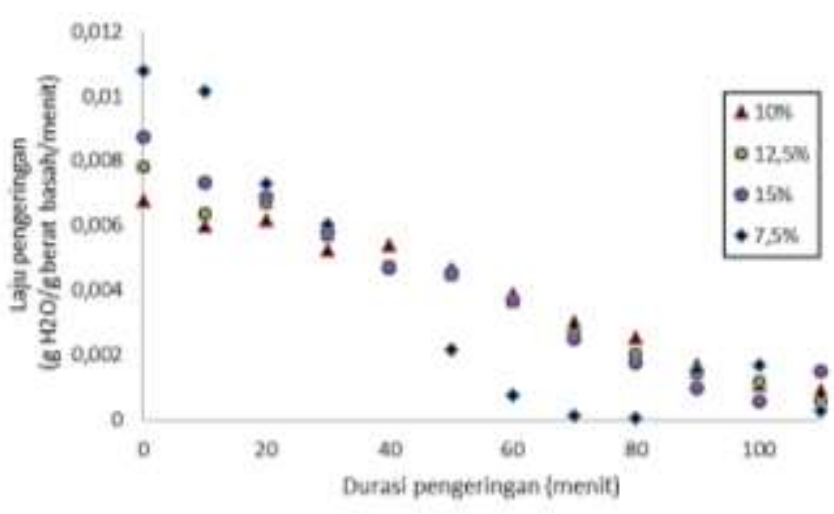

(b)

Gambar 2. Laju pengeringan (a) terhadap kadar air dan (b) terhadap durasi pengeringan

pada katu pengeringan yang semakin lama, laju pengeringannya semakin lambat. Hal tersebut dapat disebabkan pembentukan busa berisi sel udara (Gambar 3) menyebabkan peningkatan luas permukaan spesifik dari produk yang berakibat air dapat terpisah dengan cepat dari permukaan produk. Namun demikian, seiring dengan bertambahnya durasi pengeringan, foam akan mengalami collaps akibat dari proses pengosongan air yang berada disekitar sel sel udara dan menyebabkan protein pada lapisan film disekitar sel udara akan berkurang dan menipis. Pada akhirnya lapisan lamella tersebut akan semakin tipis dan tidak lagi mampu menyangga sel-sel udara (Lomakina dan Mikova, 2006). Pecahnya busa-busa tersebut akan menagibatkan turunnya luas permukaan spesifik dari produk dan menurunnya laju pengeringan.
Selanjutnya, data kadar air digunakan untuk menghitung nilai mositure ratio yang digunakan untuk mengkaji kinetika pengeringan busa ampas seduhan teh. Pada dasarnya, persamaan kinetika pengeringan pada model pengeringan lapis tipis diklasifikasikan menjadi tiga kategori yakni: (i) teoritis, (ii) semi teoritis dan (iii) empiris (Inyang et al., 2018). Pada umumnya, model teoritis biasanya diturunkan dari hukum Fick kedua (Fisk's second law). Sementara model empiris dibangun berdasarkan data eksperimen dan analisa bilangan tak berdimensi. Model semi teoritis diturunkan dari hukum Fick kedua (Fisk's second law) dan hukum pendinginan Newton (Onwude et al., 2016; Inyang et al., 2018).

Dalam penelitian ini, kinetika proses pengeringan busa ampas seduhan teh dikaji menggunakan model kinetika pengeringan lapis 
tipis Newton/Lewis, Page, Henderson-Pabis, Logartitmic dan Two Term. Komparasi nilai $\mathrm{MR}_{\text {data }}$ dan $\mathrm{MR}_{\text {calc }}$ berbagai model tersebut disajikan pada Gambar 4 dan nilai parameter dan konstanta kecepatan reaksi dari model Newton/Lewis, Page, Henderson-Pabis, Logartitmic dan Two Term disajikan pada Tabel 2. Sebagaimana tersaji pada Gambar 4 dan Tabel 2, model kinetika Page memberikan kesesuaian yang lebih tinggi bila dibandingkan dengan model Newton/Lewis,
Henderson-Pabis, Logartitmic dan Two Term. Untuk semua konsentrasi busa putih telur yang digunakan, nilai SSE model Page menunjukkan nilai yang paling kecil, berkisar antara 0,014-0,028, bila dibandingkan dengan nilai SSE pada model lain. Gambar 4 juga menunjukkan jika nilai-nilai $\mathrm{MR}_{\text {calc }}$ yang diperoleh dari simulasi menggunakan model kinetika Henderson-Pabis, Logartitmic dan Two Term, adalah sangat berimpit. Demikian pula dengan nilai SSE-nya.

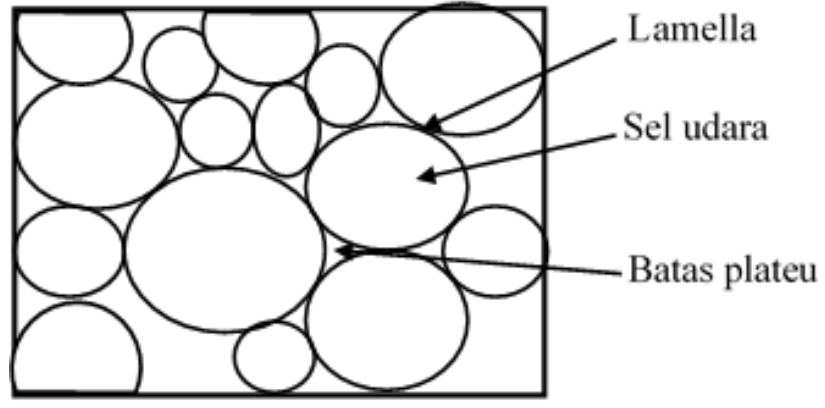

Gambar 3. Struktur busa

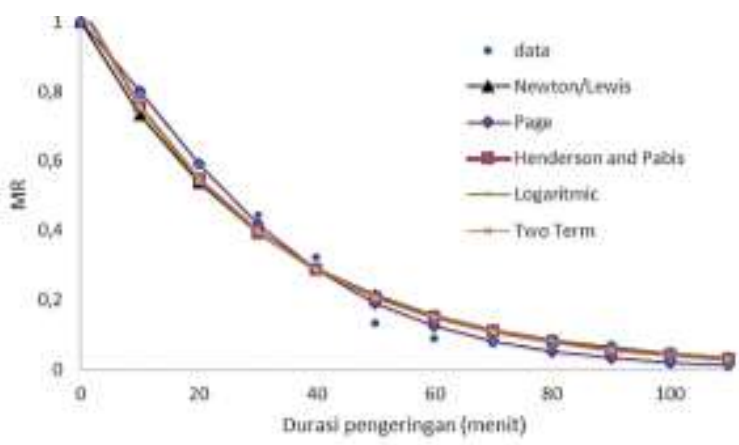

(a)

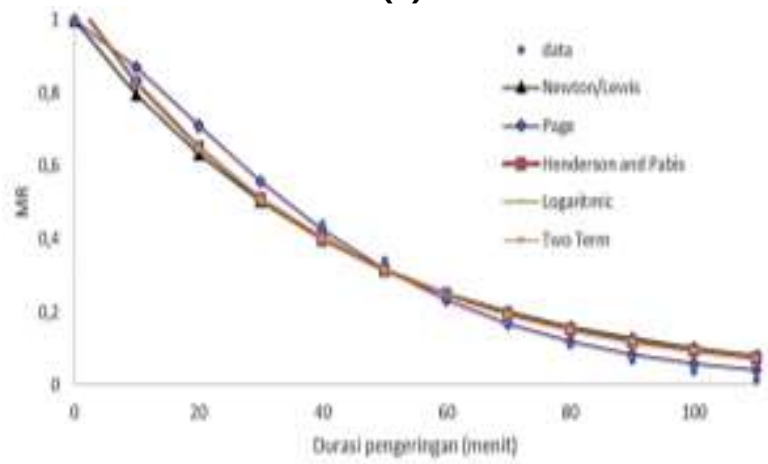

(c)

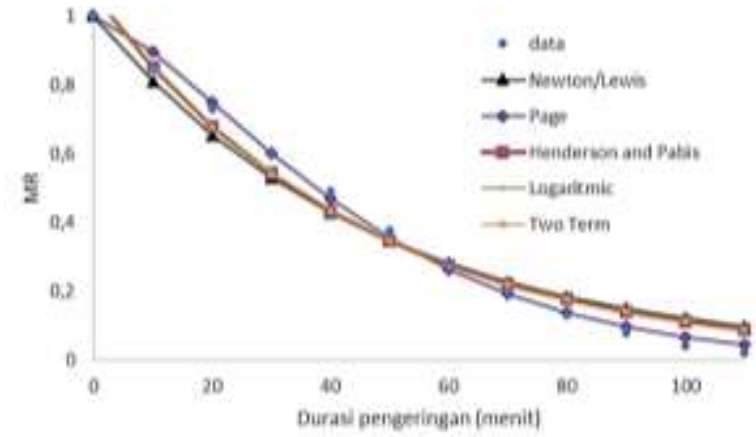

(b)

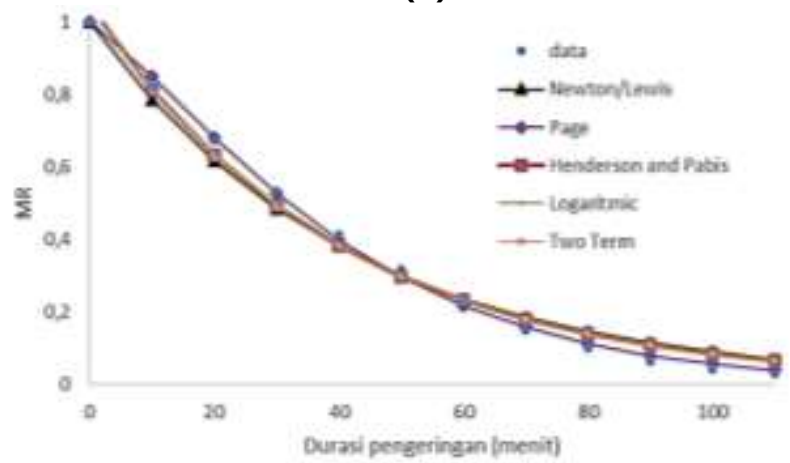

(d)

Gambar 4. Perbandingan nilai $M R_{\text {data }}$ dengan $M R_{\text {calc }}$ berdasar model kinetika Newton/Lewis, Page, Henderson-Pabis, Logaritmic dan Two Term untuk pengeringan busa ampas seduhan teh menggunakan maltodekstrin $30 \%$, suhu $80^{\circ} \mathrm{C}$ dan penambahan busa putih telur $7,5-15 \%$ 
Tabel 2. Nilai parameter kinetika pengeringan busa

\begin{tabular}{|c|c|c|c|c|c|c|c|c|}
\hline \multirow{2}{*}{ Model Kinetika Pengeringan } & \multirow{2}{*}{$\begin{array}{c}\text { Konsentrasi } \\
\text { putih telur (\%) }\end{array}$} & \multicolumn{6}{|c|}{ Parameter } & \multirow{2}{*}{ RMSI } \\
\hline & & k & $\mathrm{k}_{1}$ & A & $b$ & C & $\mathrm{n}$ & \\
\hline \multirow[t]{4}{*}{ Newton/Lewis } & 7,5 & 0,031 & & & & & & 0,043 \\
\hline & 10 & 0,021 & & & & & & 0,057 \\
\hline & 12,5 & 0,023 & & & & & & 0,048 \\
\hline & 15 & 0,024 & & & & & & 0,039 \\
\hline \multirow[t]{4}{*}{ Page } & 7,5 & 0,012 & & & & & 1,249 & 0,028 \\
\hline & 10 & 0,005 & & & & & 1,387 & 0,019 \\
\hline & 12,5 & 0,007 & & & & & 1,316 & 0,017 \\
\hline & 15 & 0,009 & & & & & 1,251 & 0,014 \\
\hline \multirow[t]{4}{*}{ Henderson-Pabis } & 7,5 & 0,032 & & 1,043 & & & & 0,040 \\
\hline & 10 & 0,023 & & 1,067 & & & & 0,051 \\
\hline & 12,5 & 0,024 & & 1,056 & & & & 0,043 \\
\hline & 15 & 0,025 & & 1,045 & & & & 0,035 \\
\hline \multirow[t]{4}{*}{ Logaritmic } & 7,5 & 0,032 & & 1,043 & & 0,000 & & 0,040 \\
\hline & 10 & 0,023 & & 1,067 & & 0,000 & & 0,051 \\
\hline & 12,5 & 0,024 & & 1,056 & & 0,000 & & 0,043 \\
\hline & 15 & 0,025 & & 1,045 & & 0,000 & & 0,035 \\
\hline \multirow[t]{4}{*}{ Two_term } & 7,5 & 0,032 & 0,032 & 0,522 & 0,522 & & & 0,040 \\
\hline & 10 & 0,023 & 0,023 & 0,533 & 0,533 & & & 0,051 \\
\hline & 12,5 & 0,024 & 0,024 & 0,528 & 0,528 & & & 0,043 \\
\hline & 15 & 0,025 & 0,025 & 0,523 & 0,523 & & & 0,035 \\
\hline
\end{tabular}

\section{KESIMPULAN}

Penambahan busa putih telur sebanyak $7,5 \%$ dan maltodekstrin $30 \%$ pada proses pengeringan ampas seduhan teh yang dilakukan pada suhu $80^{\circ} \mathrm{C}$ mampu memberikan penurunan kadar air bahan yang rendah, laju pengeringan yang cepat serta memberikan kontanta kecepatan pengeringan yang lebih tinggi bila dibandingkan penggunaan busa putih telur 10-15\%. Apabila dibandingkan dengan model kinetika Newton/Lewis, Henderson and Pabis, Logartitmic dan Two Term; model kinetika Page memberikan kesesuaian yang lebih tinggi terhadap data eksperimen.

\section{DAFTAR PUSTAKA}

Barus, N.S., Sony, S., Salman, S., Mahmudi, M. \& Sunartaty, R., 2018. Uji Toksisitas Subakut Ekstrak Daun Tembakau (Nicotiana Tabacum L.) Yang Difermentasi Terhadap Gambaran
Histologi Organ Vital Mencit (Mus Musculus). Jurnal Stikna, 2(02):33-40.

Cappelletti, S., Daria, P., Sani, G., \& Aromatario, M. 2015. Caffeine: Cognitive and Physical Performance Enhancer or Psychoactive Drug. Current Neuropharmacology, 13:71-88 Direktorat Perkebunan. 2016. Statistik Perkebunan Indonesia: Teh.

Hardy, Z. \& Jideani, V.A. 2015. Foam-mat Drying Technology: A Review. Critical Reviews in Food Science and Nutrition, 7(12):2560-2572 DOI: 10.1080/10408398.2015.1020359

Hartati, I., Kusumaningrum, M. \& Kurniasari, L. 2018. Pengeringan Busa Terhadap Ampas Seduhan Teh Menurut Model Kinetika Lewis, Page Dan Henderson-Pabis. Jurnal Inovasi Teknik Kimia, 3(1):59-66

Inyang, U.E., Oboh, I.O. \& Etuk, B.R. 2018.Kinetic Models for Drying Techniques-Food Materials. Advances in Chemical Engineering and Science. 8(2):27-48

Lomakina K., dan Mikova K. 2006. A Study of the Factors Affecting the Foaming Properties of 
Egg White - a Review. Czech Journal Food Science. 24(3):110-118

Mounir, S. 2017. Foam Mat Drying. Drying Technologies for Foods. 169-191

Onwude, D.I., Hashim, N., Janius, R.B., Nawi, N.M. and Abdan, K., 2016. Modeling the thinlayer drying of fruits and vegetables: $A$ review. Comprehensive reviews in food science and food safety, 15(3):599-618.

Ramdani, D., Chaudhry, A.S. and Seal, C.J., 2013. Chemical composition, plant secondary metabolites, and minerals of green and black teas and the effect of different tea-towater ratios during their extraction on the composition of their spent leaves as potential additives for ruminants. Journal of agricultural and food chemistry, 61(20): 4961-4967. DOI: 10.1021/jf4002439

Sangamithra, A., Venkatachalam, S., John, S.G. and Kuppuswamy, K., 2015. Foam mat drying of food materials: A review. Journal of Food Processing and preservation, 6(39), pp.31653174. DOI: 10.1111/jfpp.12421

Tfouni S.A.V., Camara M.M , Kamikata K., Gomes F.M.L., Furlani R.P.Z. 2017. Caffeine in teas: levels, transference to infusion and estimated intake. Food Science and Technology. 38(4):661-666. DOI: 10.1590/ 1678-457X.12217 